\title{
GIS-modeling of the Range Shifts of the Sub-fossil and Extant European Pond Turtle (Emys orbicularis) in Eastern Europe in Holocene
}

\author{
Oksana Nekrasova ${ }^{1, *}$, Yevheniia Yanish ${ }^{1}$, Volodymyr Tytar ${ }^{1}$ and Mihails Pupins ${ }^{2}$ \\ 1 I. I. Schmalhausen Institute of Zoology, National Academy of Sciences of Ukraine, 01030 Kyiv, Ukraine \\ 2 Department of Ecology, Institute of Life Sciences and Technologies, Daugavpils University, \\ LV5400 Daugavpils, Latvia \\ * Correspondence: oneks22@gmail.com; Tel.: +38-067-217-1970
}

Received: 27 April 2019; Accepted: 24 June 2019; Published: 26 July 2019

\begin{abstract}
The study of the dynamics of the European pond turtle's Emys orbicularis range and distribution as an indicator of climate change in the past, present, and future is most relevant in connection with the protected status of this species in Europe. Based on our original finds, 25 archaeological sites yielding 1623 remains of 1504 individuals of subfossil pond turtles, current marginal distribution in Latvia, Ukraine, Russia, and literature data, we analyzed 437 records of Holocene turtles and 2847 current records of pond turtles. We identified areas that could serve as refugia for E. orbicularis, as a result of GIS modeling, while using 19 bioclimatic variables from the Worldclim and PaleoClim data bases. The data obtained confirm current hypotheses regarding the origin of more than $10 \mathrm{mtDNA}$ lineages of E. orbicularis and the existence of multiple glacial refugia, and considerable Holocene home range dynamics.
\end{abstract}

Keywords: European pond turtle; Emys orbicularis; Holocene; glacial refugia; GIS-modeling

\section{Introduction}

The literature presents data on the reconstruction of fluctuations of the European pond turtle's Emys orbicularis (Linnaeus, 1758) home range during the Holocene period for Northern and Central Europe [1-4]. After the glaciers' melting in the early Holocene, the turtle experienced a rapid expansion of its range, and there are also findings of subfossil records of E. orbicularis in the Northern and Baltic seas, including the United Kingdom, Baltic countries, Sweden, Finland, Belarus, and Russia [4-8]. The expansion of the turtle range coincided with the Holocene climatic optimum about 10,100-5700 years ago [9]. Thus, according to some sources, the reindeer disappeared from southern Sweden ca. 10,300 years ago, whereas the pond turtle colonized the area ca. 9,860 years ago, with a 450-year gap between species [4], when the annual mean temperatures were approximately $1-2{ }^{\circ} \mathrm{C}$ higher than today. In the following climatic optimum (Atlantic), the temperatures remained $2.5^{\circ} \mathrm{C}$ higher than today for nearly 3000 years and E. orbicularis reached its maximum distribution during that time [6]. After that, the home area of the turtle underwent fluctuations, depending on temperature and other factors. Accordingly, the disappearance of the turtle from some parts of the range could have been associated with human influence [1,10]. Moreover, European pond turtles probably served as food for prehistoric humans in Vorarlberg, as indicated by the presence of turtles' bones in prehistoric settlements [11].

However, the issues of the fluctuations of the home range of the species during different periods of the Holocene have not yet been fully studied, since the literature does not contain more or less complete data on the distribution of the turtle in the eastern part of the area [12]. There are some data from Ukraine. For instance, K. A. Tatarinov [13] reported the findings of E. orbicularis dating 
back to the Pliocene-Early Holocene periods: in the Polessie (alluvial sands, Rivne region), in the Western and Central Podolia, and in the Eastern Carpathian region. Additionally, turtles' remnants were found in layers dated the Neolithic-Eneolithic, in settlements that dated back to the Bronze Age in Republic of Bashkortostan, Republic of Mari El, Republic of Tatarstan, in Samara, Nizhniy Novgorod, Orenburg regions, Russia [14]. For the most part, there is very little information from Ukraine and Russia. Therefore, the purpose of our work is to carry out research and specifically to collect data in Ukraine, Russia, and Latvia concerning the subfossil records of E. orbicularis; for comparisons our current data was used [15-19]. It was important to confirm the existing and original hypotheses, it was also necessary to conduct a GIS-analysis of the climate change's effects on the turtles' distribution. The importance and uniqueness of the collected materials is that, as a rule, the remnants of subfossil turtles do not approach zoologists for research, as archaeologists are only primarily interested in the remains of turtles that were used for ritual purposes or bearing traces of processing by man. Archaeologists usually are unable to identify fragments of bones and the carapace to the species level and these remnants are thrown out at the excavation site. Accordingly, the bulk of the pond turtles' findings are not included in archaeological publications and are used for the first time.

\section{Materials and Methods}

\subsection{Study Area}

The article was based on the material that was collected during the excavations of archaeological sites; the expedition leaders have provided all datings (Table 1). The age of the sites spans from the Neolithic to the Middle Ages, covering the territory from Crimea and the western regions of present Ukraine to Lipetsk and Voronezh regions of the Russian Federation. The large sample size, 1623 remains from 1504 individuals of subfossil pond turtles, was obtained by the archeozoologist (Ye. Yanish) from 80 archaeological sites in 2006-2018. Of these, the remains of turtles were found at 25 sites (Table 1).

Table 1. Data on the found subfossil records of E. orbicularis.

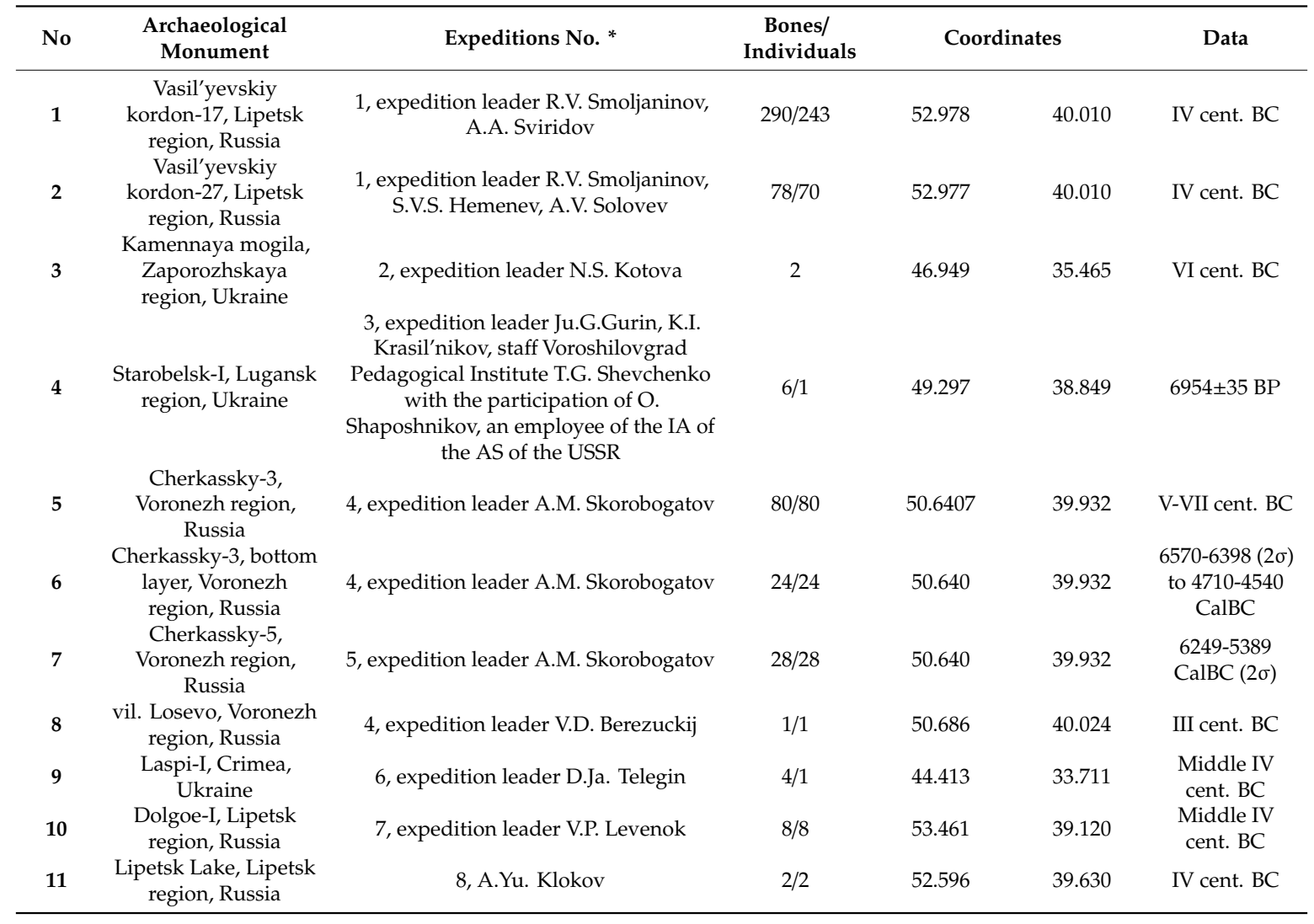


Table 1. Cont

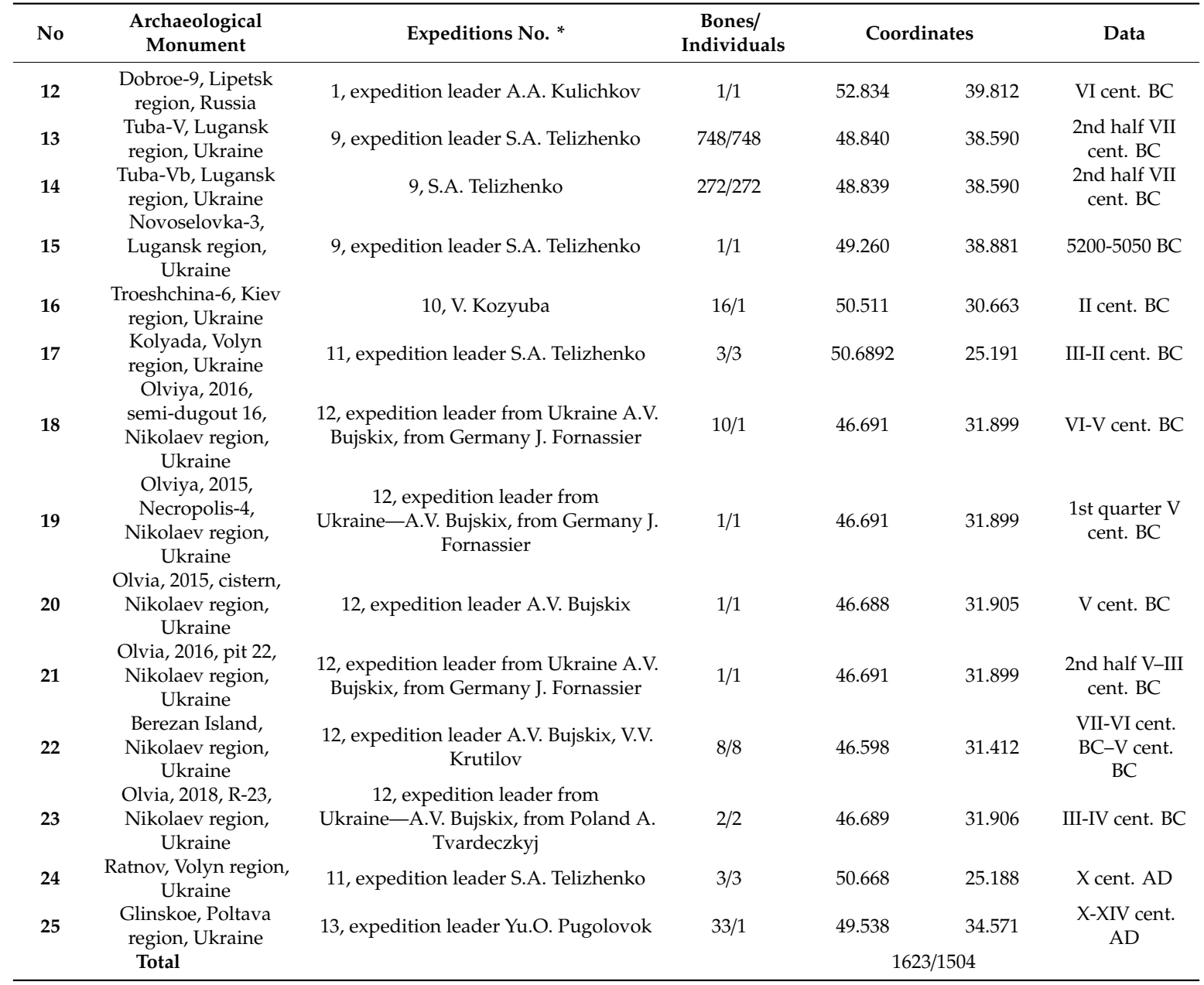

*Expeditions: 1. Lipetskaya regional scientific public organization "Archaeologist"; 2. Priazovskaya archaeological expedition of the Institute of Archeology (IA) of the National academy of science of Ukraine (NASU); 3. Excavations in 1985 in the Luhansk region; 4. VGPU expedition; 5. Expedition "Terra"; 6. Laspi detachment of the IA of the Academy of Sciences of the USSR (ASUSSR); 7. Verkhne-Donskaya archaeological expedition of the Leningrad branch of the IA ASUSSR and the Lipetsk Regional Museum of Local Lore; 8. Exploration archaeological collections A.Yu. Klokov (Lipetsk Regional Local History Society); 9. Lugansk archaeological expedition; 10. Exploration archaeological collections V.Kozyuba, IA NASU; 11. Ratnevskaya archaeological expedition, IA NASU; 12. Ol'viyskaya Complex International Expedition, the Ukrainian-Polish project of the IA NASU with the National Museum in Warsaw (Poland) or the Ukrainian-German project of the IA NASU; 13. Expedition of the Institute of Keramology-Department of the Institute of Ethnology of the NASU, with the participation of specialists from the IA NASU and the National Museum of Ukrainian Pottery in Opishne.

At the same time, the amount of all the animal bones that were examined consisted of more than 80,000 units, among which 1623 turtles' bones were found. The bones and fragments of carapaces were revealed in osteological materials and studied by the archeozoologist Ye. Yanish. Additionally, the literature data $[4-7,20]$ was used for the analysis, for which a database was created with 437 record of Holocene turtles. For comparison and GIS-analysis, the extant turtles (2847) were used: GBIF [21], Ukraine (original data of Nekrasova O.), Baltic countries (Latvia, original data of Pupins M. [5,15-19]); Belarus [8,22,23], Russia, and Kazakhstan [24-28].

\subsection{GIS Modelling}

GIS-analysis of the climate change's effects on the turtles' distribution was accomplished while using the Maxent algorithm, proven for the good performance and accuracy for species distribution modelling (SDM) studies [29]. Maxent is a machine learning algorithm, the main advantage of which is that, in comparison with other methods, it only needs presence point data, besides the environmental 
layers. Pseudo-absence points are randomly generated and used instead of true absences. Maxent provides output data in various formats. The logistic format (values range from 0 to 1 ) is recommended, because it allows for an easier and potentially more accurate interpretation of habitat suitability when compared to the other approaches [30]. The performance of the Maxent models are evaluated by the receiver operating characteristic (ROC) approach and calculating the area under the ROC curve (AUC) as a measure of prediction success. Values that are greater than 0.5 indicate a better-than-random performance event and higher values of $0.6-0.8,0.8-0.9$, and $0.9-1.0$ are considered of "good", "very good", and "excellent" performance, respectively [31]. WorldClim [32] and PaleoClim [33] were the climate data sets used. These are sets of global climate layers (gridded climate data; we used a 10 arcmin resolution), including temperature and precipitation, and 19 bioclimatic variables that were derived from the monthly temperature and rainfall values in order to generate biologically meaningful variables. These are often used in SDMs and related ecological modeling techniques. The bioclimatic variables represent annual trends, seasonality, and extreme and/or limiting environmental factors. In PaleoClim, these akin to WorldClim have been reconstructed for the early-, mid-, and late Holocene.

Bioclimatic variables are coded as follows are coded, as follows:

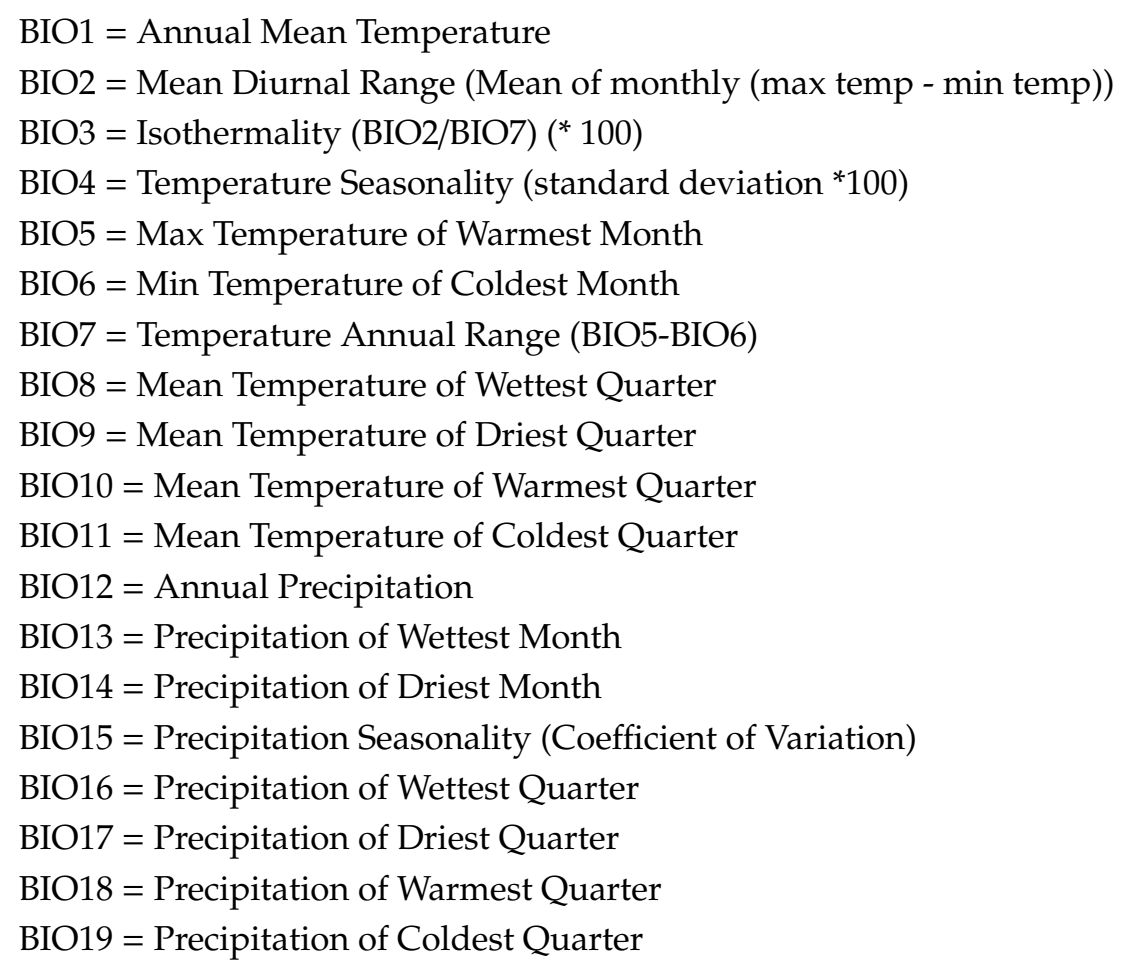

\section{Results}

Large accumulations of turtles' remains were found as a result of investigation of 25 archaeological sites, from which up to 748 individuals were identified (Table 1, Figure 1). 


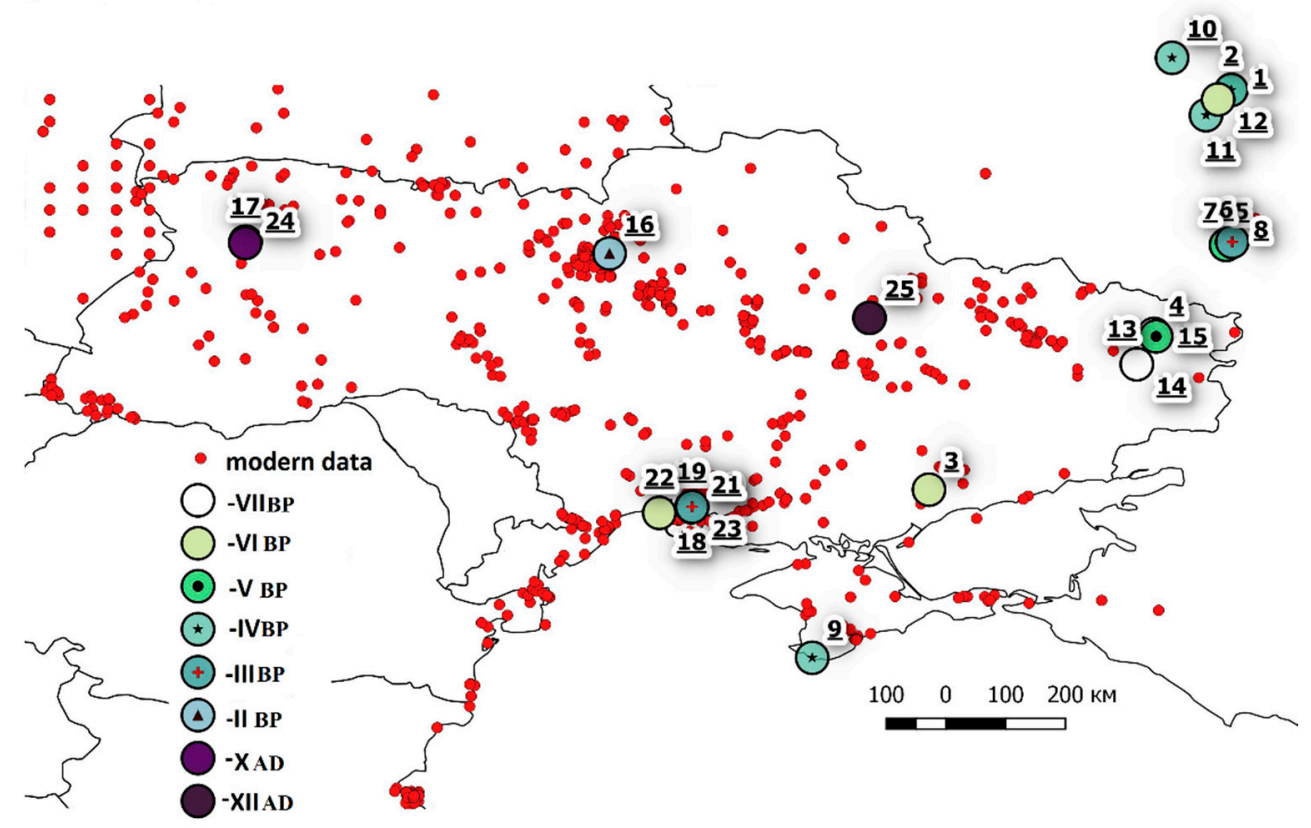

Figure 1. Map of subfossil records (from VII BP to XII AD: Ukraine, Russia) of E. orbicularis (Table 1).

Individual fragments and single specimens were more common, but accumulations of bone remains were found in the Lipetsk region (Russia), 243 specimens in one place, and in the Luhansk region (Ukraine), 272 individuals, and 748 individuals in two places. Such unique findings of remains' clusters are most likely explained by culinary preferences, and possibly the traditional uses of turtles not only for culinary, but also for other practical purposes: sometimes turtle's carapace was used as a dish or decoration. Such traditional exchanges of turtle artifacts or pets between human settlements could lead to the appearance of turtle remnants or even live animals in the most unusual places. However, only suitable climatic conditions can support the survival of alien turtles in a natural habitat. Therefore, it is necessary to analyze, not only the findings of turtles themselves, but also the climatic conditions of those distant ages while using paleoclimatic data.

When comparing our unique archaeological findings with the modern distribution of pond turtles, we came to the conclusion that turtles that were found around the Black Sea and on the adjacent islands (Berezan, Olbia of Mykolaiv region, Ukraine) are of particular interest [34]. Today, brackish water surrounds these habitats and are not very suitable for present turtles. According to paleoclimatic data, these places were marshlands with fresh water in the early Holocene. The Black Sea level was $105 \mathrm{~m}$ lower than today aound 10,000 years ago, and the delta estuaries (Danube-Don) were united into a single delta system [35]. 1623 remains of 1504 individuals of subfossil pond turtles (Figures 2 and 3a) were found in the "Neolithic settlement" archaeological finding as a result of field studies (2006-2018) that covered 25 archaeological sites.

In addition, our research in Latvia [15-19], Russia, and Ukraine most fully helped to study the current distribution of the pond turtle. We analyzed 437 records of Holocene turtles and 2847 current records while using the obtained database (original and literary data). We discovered areas that in the past could serve as glacial refugia for E. orbicularis by performing a GIS-modeling procedure and using 19 bioclimatic variables from the Worldclim and PaleoClim databases. The data obtained confirms hypotheses that were expressed by other authors regarding the origin of more than 10 mitochondrial lineage and eight subspecies [3,6,36-41]. 


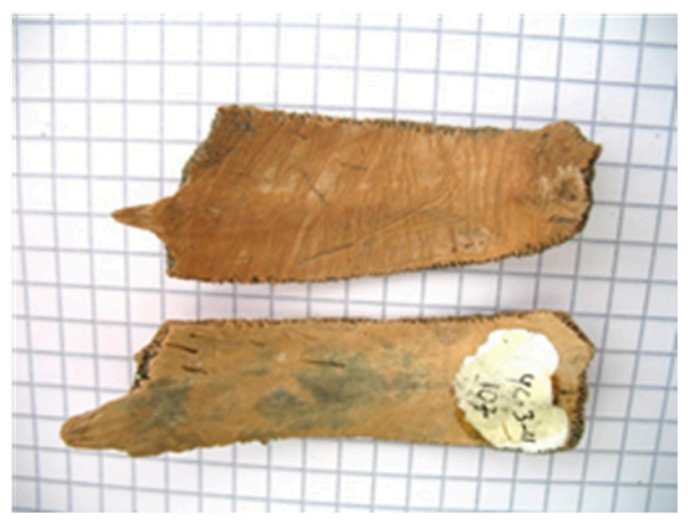

(a)

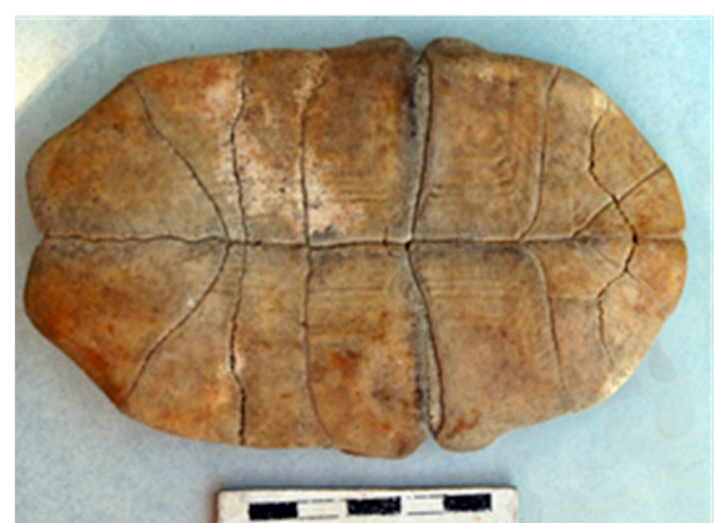

(b)

Figure 2. Fragments of the carapace (a) and plastron (b) of a pond turtle: (a, top image)—with sign of kitchen knife cutting, (a, lower image)—without a trace of cutting, for comparison, Neolithic, Cherkasskoe-3 (Voronezh region, Russian Federation, foto Ye. Yanish) and (b)—Antiquity, Olbia (Mykolaiv region, Ukraine, foto A. Buyskikh).

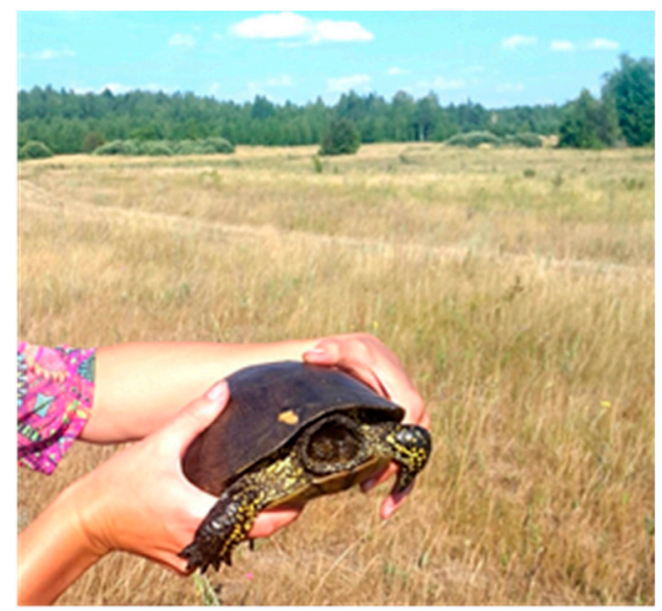

(a)

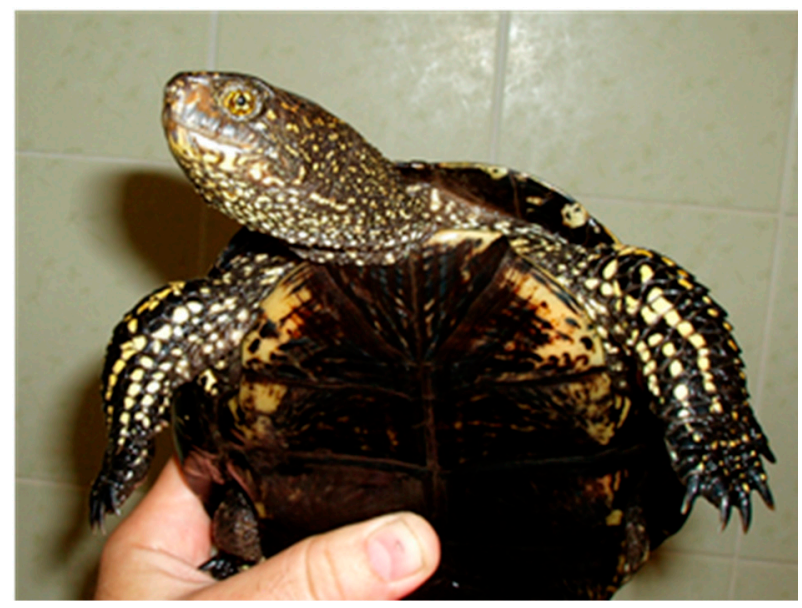

(b)

Figure 3. (a)-E. orbicularis, was caught an near site of the Neolithic settlement Vasilievsky cordon-27 (located in a meadow nearby a forest). After five years of research nearby the Voronezh River this is the first record of the species here (foto A. Zheludkov, 2018). (b)-E. orbicularis adult female caught in Ance, Ventspils novads, Latvia. This is one of European northernmost modern records of the species (foto M. Pupins, 2007).

The received GIS-model (SDM) of the Early Holocene (Figure 4) clearly shows that the advancement to the north of the turtle range was also possible, thanks to the land bridges between the mainland and the peninsulas, when considering that the Baltic Sea was freshwater then [6,42]. During different periods of the Holocene, the climate could change and the turtle range varied accordingly. Subsequently, the onset of boreal and other northern elements to the south and west occurred during the cool-wet inter-century era of the second half of the XVth century-the end of the IXth century ("Little Ice Age") [14]. The turtle has disappeared from many northern marginal localities. 


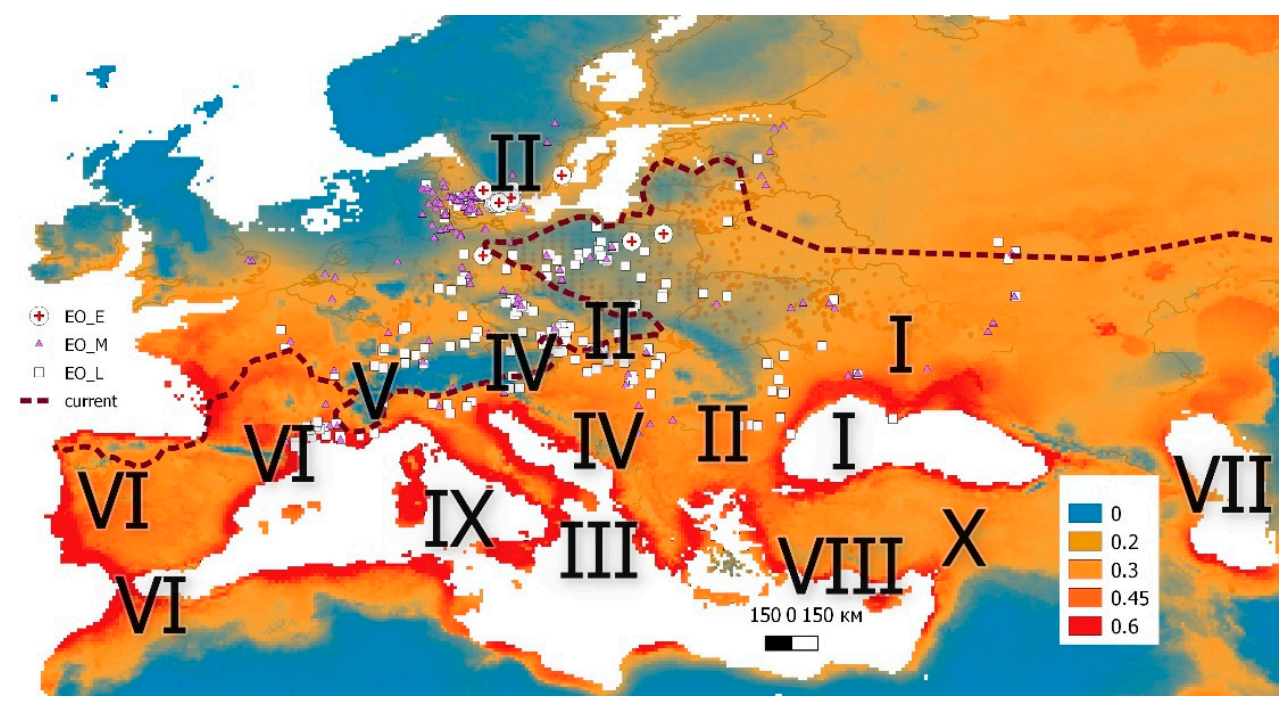

Figure 4. GIS-model of the Early Holocene location of glacial refuges (red) of Europe by E. orbicularis based numerals refer to mtDNA: I-X [3-5,43-45], Holocene subfossil finds records in Europe: EO_E-Early Holocene, EO_M-Middle Holocene, EO_L—Late Holocene [5-7,23], original data), the line displays the current northern distribution border of native populations $[3-5,7,8,33]$.

An opposite trend is expected by 2020-2030. Current trends in climate change confirm that the turtles' range is expanding in the north-eastern direction in the present and future. Further expansion of the species to the Baltic countries is possible, according to our forecasts (GIS-model). Interestingly, the archaeological finding in the "Neolithic settlement Vasil'yevskiy kordon-27", where the remains of up to 70 individuals of turtles, which today coincides with the modern-day marginal north-eastern findings of turtles in the Lipetsk region $\left(2018,52.97^{\circ} \mathrm{N}, 40.01^{\circ} \mathrm{E}\right.$, Figure 1 (record No. 2), Figure 3a). Earlier (about five years ago), the turtles were not registered here.

Pulsation of the turtles' homerange was observed throughout the Holocene, especially in the northern part of their range. From 1820 to 1927, a total of 12 turtles' occurrence points were recorded [10,43]. Modern records included 19 new findings of E. orbicularis (1970-2017) that herpetologists in Latvia confirmed, including the northern part of the country [15-19] (Figure 3b).

The research has shown the existence of ten deeply divergent mitochondrial lineages with many haplotypes, which correspond to a pronounced phylogeographic structure [3,36,37]. When studying local turtles' populations while using genetic methods in different countries (for example-Austria, Czech Republic, Corsica, and Sardinia islands, etc.), it was found that most of them are introduced species $[11,20,39,40]$. While using genetic methods, it is possible to oftenly differentiate between the native and introduced turtles. In addition, until the 1980s, huge numbers of European pond turtles were sold as pets [37]. Pet turtles can escape or be released into the wild [44,46,47].

The results of GIS modeling confirm the previously described hypotheses of the origin of seven mtDNA genetic lineages: I-eastern Europe and Asia Minor, II-central Europe and central Balkan, III-southern Italy, IV—around the Adriatic Sea, V-the northwest coast of the Mediterranean, VI-Iberia and Northern Africa, VII-the Caspian region, VIII-southern coast of Turkey, and IX—eastern Algeria, Tunisia (Figure 4 [3,6,36-38,41]).

Turtles' distribution is associated with climate, and the key factors that determine the survival of northern populations include adequate temperature and level of solar radiation in summer, which are necessary for the successful incubation of eggs $[1,2,6,10,22,23]$.

\section{Discussion}

The data obtained confirms the hypotheses that are described in the literature regarding the existence of at least 10 major refugia, where new genetic lineages were formed ([3,5,43]; Figure 4). 
The leading role in the formation of landscapes in the Holocene was played by climatic factors: a decrease or increase in the temperature of the growing season, decrease or increase in the severity of the winter period, and human activity. The spreading of most species of vertebrates in the Holocene of Eastern Europe proceeded within the framework of six macroclimatic cycles that developed in the range of 1500-2000 years [14]. Post-glacial recolonization of European biota expaned northward from southern refugia [42]. Perhaps it is the western part of Europe that is interesting in terms of recolonization and numbers of refugia-most of them appear to be found on the Iberian Peninsula [41]. In addition, the movement of many species' ranges in the Holocene of Eastern Europe went in the direction not only south $\leftrightarrow$ north, but very often east $\leftrightarrow$ west [14].

The GIS-model (SDM) of the Early Holocene that we received (Figure 4) clearly shows that the advancement to the north of the turtle range was also possible thanks to the land bridges between the mainland and the peninsulas existing at that time (for example, in southern Sweden at $8.5 \mathrm{ka}$ BP (7.5 ka cal BC). In those times, the annual mean temperatures were above $2.5^{\circ} \mathrm{C}$ higher than today, and E. orbicularis reached its maximum distribution, when considering that the Baltic Sea was then a freshwater lake [6]. The northeastern boundary of the turtles' habitat at the end of the Mesolithic and Neolithic-Eneolithic passed some 100-200 km to the north, and in the Late Bronze Age-the Middle Ages, the northern border of the range passed some $50-100 \mathrm{~km}$ to the north in comparison to the current situation (Republic of Tatarstan) [14].

However, the dynamics of the turtles' habitat was very dependent on climatic factors, which greatly changed during the Holocene (for example, in the Subboreal) [4]. A significant reduction in the nemoral and thermophilic fauna and the onset of boreal and other northern elements to the south and west occurred during the cool-wet inter-century era of the second half of XV century-the end of IX century ("Little Ice Age"), as can be seen from the studies of the home ranges [14]. The increase in turtles' range is only possible with the next warming. Hence, according to modern data, such dynamics (the pulsation of the home range) is well traced in recent times due to the warming trends observed in the northern part of the turtles' home range.

Therefore, it is such that animals, such as turtles, can be good indicators of climate change. This is because they are very dependent on climatic factors, like temperature and humidity. Their distribution is related to the climate, and the key factors include sufficient temperature and solar radiation levels in summer, which are necessary for the successful incubation of eggs [22]. However, sharp cooling, as well as a drastic warming and influence of various anthropogenic factors, can lead to negative consequences, both for the species and for its food supply, which significantly reduces its home range [45]. Only recently the literature data has appeared on the advancement of the turtles' home range in a north-eastern direction. Today, it covers from Portugal to Asia (Kazakstan, Iran, Syria, and Turkey), Morocco, Algeria, and Tunisia. The northernmost populations are found in northeast Germany, Poland, Lithuania, and southern and central Latvia $[6,7,15-19]$. Such shifts of the range in a north-eastern direction are also characteristic of other herpetofauna species, the distribution of which is associated with the factors of precipitation and/or humidity [48]. Spreading can also occur due to the anthropogenic factor. Therefore, it is very important to analyze the potentially possible habitats of turtles in the present and future while using GIS-modeling.

Our preliminary data shows that, under the considered habitat suitability threshold of $0.1,82 \%$ of Latvia holds suitable locations, primarily in the west and south of the country, and a small portion $(14 \%)$ in south-west [49]. The resulting Maxent model showed a "very good" prediction (AUC=0.829), which was greater than the 0.5 of a random model. Estonia may also have favorable conditions for the species [19]. However, the currently predicted habitat suitability in this border area is yet fairly low (median $=0.35$, as compared to 0.49 in Ukraine) due to insufficient heat accumulation in a cold-climate region (indicated in the model by low numbers of growing degree-days with mean temperature greater than $0{ }^{\circ} \mathrm{C}$ ). Climate changes with warming trends are very likely to support the northward expansion of the European pond turtle and help the species to gain a stronger foothold in the Baltic region. 


\section{Conclusions}

As a result of field studies (2006-2018) covering 25 archaeological sites, 1623 remains of 1504 individuals of subfossil pond turtles (Figures 1-3) were found. In addition, our research in Latvia, Russia, and Ukraine most fully helped to study the current distribution of the pond turtle. We analyzed 437 records of Holocene and 2847 present records of pond turtles while using the obtained database (original and literary data). We discovered areas that in the past could serve as glacial refugia for E. orbicularis by performing a GIS-modeling procedure and using 19 bioclimatic variables from the Worldclim and PaleoClim data bases. The obtained data confirms hypotheses that are expressed by other authors about the origin of more than 10 mitochondrial lineage and about eight subspecies [3,6,36-38,41]. The GIS-model (SDM) of the Early Holocene that we received (Figure 4) clearly shows that the advancement to the north of the turtle range was also possible, thanks to the land bridges between the mainland and the peninsulas, when considering that the Baltic Sea was then a freshwater lake [6,42]. During different periods of the Holocene, the climate could change and the turtle range varied accordingly. Subsequently, the onset of boreal and other northern elements to the south and west occurred during the cool-wet inter-century era of the second half of the 15th century-the end of the 19th century ("Little Ice Age") [14]. The turtle has disappeared from many northern marginal localities. The opposite situation is expected by the 20-30th year of the XXI century. Current trends in climate change confirm that turtles' range is expanding in the north-eastern direction in the present and future. Further expansion of the species to the Baltic countries is highly likely, according to our forecasts (GIS-model).

Author Contributions: Conceptualization, O.N., Y.Y. and V.T.; Data curation, O.N. and M.P.; Formal analysis, O.N. and V.T.; Funding acquisition, M.P.; Investigation, O.N., Y.Y. and M.P.; Methodology, O.N., Y.Y. and V.T.; Project administration, O.N., V.T. and M.P.; Resources, O.N., Y.Y. and M.P.; Software, O.N. and V.T.; Supervision, O.N., V.T. and M.P.; Validation, O.N., V.T. and M.P.; Visualization, O.N., V.T. and M.P.; Writing一original draft, O.N.; Writing—review \& editing, Y.Y., V.T. and M.P.

Funding: This research received no external funding.

Acknowledgments: The reseacrh was conductet in accordance with legislation of Latvia and Ukraine. We thank for cooperation Daugavpils University, Daugavpils municipality, Latgales Zoo, VIAA project Nr. LV-UA/2018 "The ecological and biological triggers of expansion of the invasive fish, Chinese sleeper (Perccottus glenii), in Eastern Europe". We thank Oleksii Marushchak for assistance in preparing the article.

Conflicts of Interest: The authors declare no conflict of interest.

\section{References}

1. Fritz, U. Zur innerartlichen variabilität von Emys orbicularis (Linnaeus, 1758). 5b. Intraspezifische Hierarchie und Zoogeographie (Reptilia: Testudines: Emydidae). Zool. Abh. Staatl. Mus. Tierkd. Dresd. 1996, 49, 31-71.

2. Fritz, U. Emys orbicularis (Linnaeus, 1758)_Europäische Sumpfschildkröte. In Handbuch der Reptilien und Amphibien Europas; Fritz, U., Schildkröten, I., Eds.; Aula-Verlag: Wiebelsheim, Germany, 2001; pp. 343-515.

3. Fritz, U.; Laufer, H. Europaische Sumpfschildkrote, Emys orbicularis (Linnaeus, 1758). In Die Amphibien und Reptilien Baden-Wurttembergs; Laufer, H., Fritz, C., Sowig, P., Eds.; Ulmer: Stuttgart, Germany, 2007; pp. 511-524.

4. Sommer, R.S.; Fritz, U.; Seppä, H.; Ekström, J.; Persson, A.; Liljegren, R. When the pond turtle followed the reindeer: Effect of the last extreme global warming event on the timing of faunal change in Northern Europe. Glob. Chang. Biol. 2011, 17, 2049-2053. [CrossRef]

5. Berdnikovs, S. The Holocene history of the European pond tortoise (Emys orbicularis L.) in the East Baltic Area. Proc. Latv. Acad. Sci. 1999, 53, 87-92.

6. Sommer, R.S.; Persson, A.; Wiesecke, N.; Fritz, U. Holocene recolonization and extinction history of the pond turtle, Emys orbicularis (L., 1758), in Europe. Quat. Sci. Rev. 2007, 26, 3099-3107. [CrossRef]

7. Sommer, R.S.; Lindqvist, C.; Persson, A.; Bringsøe, H.; Rhodin, A.G.J.; Schneeweiss, N.; Široký, P.; Bachmann, L.; Fritz, U. Unexpected early extinction of the European pond turtle (Emys orbicularis) in Sweden and climatic impact on its Holocene range. Mol. Ecol. 2009, 18, 1252-1262. [CrossRef] [PubMed]

8. Bakharev, V.A. The history of the area Emys orbicularis (Testudines, Emydidae) and the current state of its borders within Belarus. Praci Ukrainskogo Gerpetologichnogo Tovaristva 2014, 5, 12-19. (In Russian) 
9. Rosengren, E. The colonisation history of the Scandinavian fauna presented through subfossil finds along one of Its major Immigration Routes; Scania, Southern Sweden. Environ. Ecol. Res. 2015, 3, 143-149. [CrossRef]

10. Fritz, U. Die Europaische Sumpfschildkrote (Emys orbicularis); Laurenti Verlag: Bielefeld, Germany, 2003.

11. Kleewein, A.; Wöss, G. Status of the European pond turtle, Emys orbicularis (Reptilia: Testudines: Emydidae) in Vorarlberg, Austria. Acta Herpetol. 2013, 8, 65-67.

12. Vamberger, M.; Fritz, U. Big data can cause big mistakes: Using the Societas Europaea Herpetologica atlas by Sillero et al. (2014), the distribution of Emys orbicularis will be misunderstood. Biologia 2018, 73, 281-283. [CrossRef]

13. Tatarinov, K.A. Pliocene-anthropogenic and prescription fauna of amphibians of reptiles of Volyn Polesie, Podolia and eastern Carpathians. In Voprosy Gerpetologii; Nauka: Moscow, Russia, 1973; pp. 176-177. (In Russian)

14. Askeev, I.V.; Askeev, O.V.; Galimova, D.N. Vertebrates, the natural environment and man in the Holocene of the Volga-Kama region. In Proceedings of the Materials of the Second Scientific Conference Dynamics of Ecosystems in the Holocene, Chelyabinsk, Russia, 12-14 October 2010; Smirnov, N.G., Ed.; Rifey: Yekaterinburg, Russia, 2010; pp. 20-24. (In Russian).

15. Meeske, A.C.M.; Pupins, M.; Rybczynski, K. Erste Ergebnisse zur Verbreitung und zum Status der Europäischen Sumpfschildkröte (Emys orbicularis) am nördlichen Rand ihrer Verbreitung in Litauen und Lettland. Zeitschr. Feldherpetol. 2006, 13, 71-99.

16. Pupins, M.; Pupina, A. Distribution of European pond turtle Emys orbicularis (LINNAEUS, 1758) on the northern edge of its area in Latvia. Rev. Esp. Herpetol. 2008, 22, 149-157.

17. Pupins, M.; Pupina, A. The data on the observations of the European pond turtle (Emys orbicularis L.) at the northern edge of its area in Latvia. Acta Biol. Univ. Daugavp. 2008, 8, 35-46.

18. Pupins, M.; Pupina, A.; Bakharev, V.A. The spread of the European pond turtle (Emys orbicularis L., 1758) in Latvia and in the territories bordering Belarus. Vesn. Mazyrsk. dzyarzh. ped. y̆niv. IP Shamyakina 2010, 1, 35-38. (In Russian)

19. Pupins, M.; Pupina, A. Updated distribution of the European Pond Turtle, Emys orbicularis (L., 1758) (Emydidae) on the extreme northern border of its European range in Latvia. Acta Zool. Bulg. 2017, 10, 133-137.

20. Široký, P.; Stuchlík, S.; Fritz, U.; Moravec, J. Basic morphological data of native Czech Emys orbicularis revealed by subfossil finds. Biologia 2009, 64, 795-797. [CrossRef]

21. GBIF.org Emys Orbicularis (Linnaeus, 1758) in GBIF Secretariat (2017). GBIF Backbone Taxonomy. Checklist Dataset. Available online: https://doi.org/10.15468/dl.62qcmk (accessed on 9 March 2019).

22. Drobenkov, S.M. Population Ecology of the European Pond Turtle (Emys orbicularis) in Belarus; Belarusskaja Nauka: Minsk, Belarus, 2012. (In Russian)

23. Drobenkov, S.M. Current state, anthropogenic threats and conservation of the European pond turtle (Emys orbiclularis) in Belarus. Acta Biol. Univ. Daugavp. 2014, 14, 29-36.

24. Bakiev, A.G. Emys orbicularis bog turtle in the Samara region (regional summary). In Actual Problems of Herpetology and Toxicology (Collection of Scientific Papers); IEVB RAN: Tolyatti, Russia, 2001; Volume 5, pp. 3-18. (In Russian)

25. Zavialov, E.V.; Tabachishin, V.G.; Shlyakhtin, G.V. Recent distribution habitat of reptiles in the North of Low Volga region. Sovr. gerpetol. 2004, 2, 54. (In Russian)

26. Khabibullin, V. Distribution of Emys orbicularis in the South Urals, Russia. Biol. Bratislava. 2004, 59, $27-32$.

27. Borisova, N.; Urykina, L. About new findings of the European magnetic turtle-Emys orbicularis (Linnaeus, 1758) (Reptilia, Chelonii, Emydidae)-In the Chuvash republic. In Natural Science Research in Chuvashia: Materials of Reports of the Regional Scientific-Practical Conference (Cheboksary, 21 November 2017); Plakat: Cheboksary, Russia, 2017; Volume 4, p. 80. (In Russian)

28. Dujsebayeva, T.; Brushko, Z.; Saraev, F.; Bidashko, F. Distribution of the marsh turtle Emys orbicularis (Linnaeus, 1758) on the eastern periphery of the species (Kazakhstan) Spatial Time Dynamics Biota and Ecosystems Aralo-Caspian Pool. In Proceedings of the II International Conference, Orenburg, Russia, 9-13 October 2017; pp. 174-183. (In Russian).

29. Elith, J.; Phillips, S.J.; Hastie, T.; Dudík, M.; En Chee, Y.; Yates, C.J. A statistical explanation of MaxEnt for ecologists. Divers. Distrib. 2011, 17, 43-57. [CrossRef]

30. Baldwin, R.A. Use of maximum entropy modeling in wildlife research. Entropy 2009, 11, 854-866. [CrossRef]

31. Swets, J. Measuring the accuracy of diagnostic systems. Science 1988, 240, 1285-1293. [CrossRef] [PubMed] 
32. Hijmans, R.J.; Cameron, S.E.; Parra, J.L.; Jones, P.G.; Jarvis, A. Very high resolution interpolated climate surfaces for global land areas. Int. J. Climatol. 2005, 25, 1965-1978. [CrossRef]

33. Brown, J.L.; Hill, D.J.; Dolan, A.M.; Carnaval, A.C.; Haywood, A.M. PaleoClim, high spatial resolution paleoclimate surfaces for global land areas. Sci. Data 2018, 5, 180254. [CrossRef] [PubMed]

34. Nekrasova, O.D.; Oskikro, O.S. Significant areas of the Steppe zone of Ukraine and their importance in preservation of the turtle Emys orbicularis (Linnaeus, 1758). In Proceedings of the Scientific-Practical Conference Protected Case in the Steppe Zone of Ukraine (for the 90th Anniversary of Creation of the Admiralty Reserve), Donetsk Region, Ukraine, 14-15 March 2017; Volume 2, pp. 264-269.

35. Varushchenko, S.I. Analysis of the Late Pleistocene and Holocene history of the development of the natural environment of the northwestern shelf of the Black Sea. In The Fluctuations of the World Ocean Level and Issues of Marine Geomorphology; Nauka: Moscow, Russia, 1975; pp. 50-62. (In Russian)

36. Lenk, P.; Fritz, U.; Joger, U.; Wink, M. Mitochondrial phylogeography of the European pond turtle, Emys orbicularis (Linnaeus 1758). Mol. Ecol. 1999, 8, 1911-1922. [CrossRef] [PubMed]

37. Fritz, U.; Ayaz, D.; Hundsdörfer, A.K.; Kotenko, T.; Guicking, D.; Wink, M.; Tok, C.V.; Çiçek, K.; Buschbom, J. Mitochondrial diversity of European pond turtles (Emys orbicularis) in Anatolia and the Ponto-Caspian region: Multiple old refuges, hotspot of extant diversification and critically endangered endemics. Organ. Divers. Evol. 2009, 9, 100-114. [CrossRef]

38. Stuckas, H.; Velo-Antón, G.; Fahd, S.; Kalboussi, M.; Rouag, R.; Arculeo, M.; Marrone, F.; Sacco, F.; Vamberger, M.; Fritz, U. Where are you from, stranger? The enigmatic biogeography of North African pond turtles (Emys orbicularis). Organ. Divers. Evol. 2014, 14, 295-306. [CrossRef]

39. Velo-Antón, G.; Wink, M.; Schneeweiss, N.; Fritz, U. Native or not? Tracing the origin of wild-caught and captive freshwater turtles in a threatened and widely distributed species (Emys orbicularis). Conserv. Genet. 2011, 12, 583-588. [CrossRef]

40. Pedall, I.; Fritz, U.; Stuckas, H.; Valdeón, A.; Wink, M. Gene flow across secondary contact zones of the Emys orbicularis complex in the Western Mediterranean and evidence for extinction and re-introduction of pond turtles on Corsica and Sardinia (Testudines: Emydidae). J. Zool. Syst. Evol. Res. 2011, 49, 44-57. [CrossRef]

41. Pöschel, J.; Heltai, B.; Graciá, E.; Quintana, M.F.; Velo-Antón, G.; Arribas, O.; Valdeón, O.; Wink, M.; Fritz, U.; Vamberger, M. Complex hybridization patterns in European pond turtles (Emys orbicularis) in the Pyrenean Region. Sci. Rep. 2018, 8, 15925. [CrossRef]

42. Hewitt, G.M. Post-glacial re-colonization of European biota. Biol. J. Linn. Soc. 1999, 68, 87-112. [CrossRef]

43. Silins, J.; Lamsters, V. Latvian Reptiles and Amphibians; Valters un Rapa: Riga, Latvia, 1934; p. 96. (In Latvian)

44. Pupins, M. First report on recording of the invasive species Trachemys scripta elegans, a potential competitor of Emys orbicularis in Latvia. Acta Univ. Latv. 2007, 273, 37-46.

45. Kuybida, V.V.; Nekrasova, O.D.; Kutsokon, Y.K.; Lopatynska, V.V.; Truskavetska, I.Ya. Summer Fish Kills in the Kaniv Reservoir. Hydrobiol. J. 2019, 55, 103-106. [CrossRef]

46. Pupins, M.; Pupina, A. First records of 5 allochthonous species and subspecies of turtles (Trachemys scripta troostii, Mauremys caspica, Mauremys rivulata, Pelodiscus sinensis, Testudo horsfieldii) and new records of subspecies Trachemys scripta elegans in Latvia. Manag. Biol. Invas. 2011, 2, 69-81. [CrossRef]

47. Pupina, A.; Pupins, M. First records of new aquatic predator Pelodiscus sinensis (Wiegmann 1835) in Latvia and preliminary ecological risk assessment of the invasion for autochthonic Emys orbicularis (Linnaeus 1758). Acta Biol. Univ. Daugavp. 2016, 16, 61-76.

48. Tytar, V.; Nekrasova, O.; Pupina, A.; Pupins, M.; Oskyrko, O. Long-term bioclimatic modelling the distribution of the Fire-Bellied toad, Bombina bombina, under the influence of global climate change. Vest. Zool. 2018, 52, 553-556. [CrossRef]

49. Nekrasova, O.; Tytar, V.; Pupins, M. Bioclimatic limitations to the geographical distribution of Emys orbicularis (Linnaeus, 1758) (Testudines: Emydidae) in the North of the range. In Book of abstracts. XV Portuguese-Spanish Herpetology Congress and XIX Spanish Congress of Herpetology. Biology and Conservation of Herps in the Anthropocene; Congreso de Herpetologia: Salamanca, Spain, 2018; p. 106.

(C) 2019 by the authors. Licensee MDPI, Basel, Switzerland. This article is an open access article distributed under the terms and conditions of the Creative Commons Attribution (CC BY) license (http://creativecommons.org/licenses/by/4.0/). 